Provided for non-commercial research and education use. Not for reproduction, distribution or commercial use.

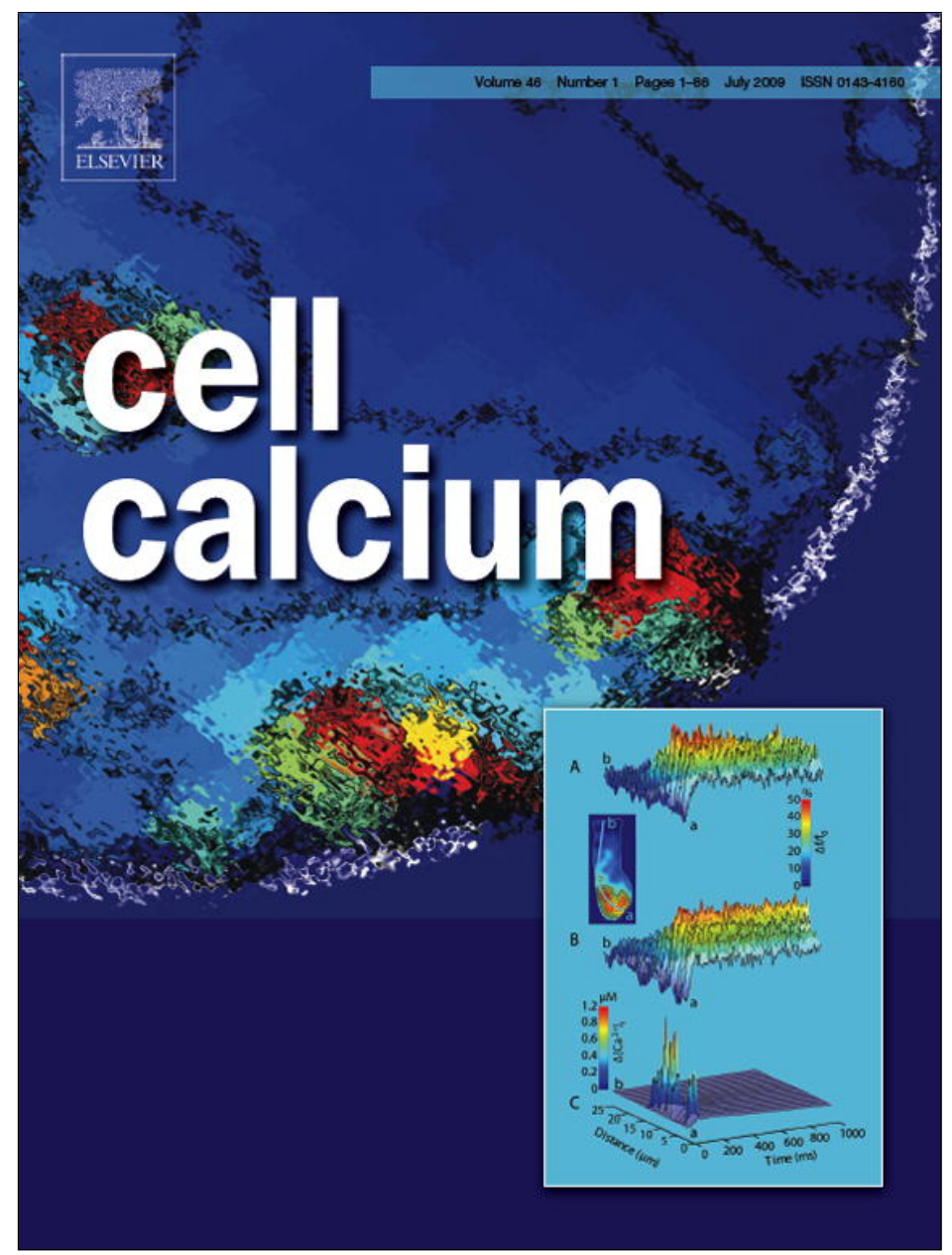

This article appeared in a journal published by Elsevier. The attached copy is furnished to the author for internal non-commercial research and education use, including for instruction at the authors institution and sharing with colleagues.

Other uses, including reproduction and distribution, or selling or licensing copies, or posting to personal, institutional or third party websites are prohibited.

In most cases authors are permitted to post their version of the article (e.g. in Word or Tex form) to their personal website or institutional repository. Authors requiring further information regarding Elsevier's archiving and manuscript policies are encouraged to visit:

http://www.elsevier.com/copyright 


\title{
Regulation of inositol 1,4,5-trisphosphate receptor type 1 function during oocyte maturation by MPM-2 phosphorylation
}

\author{
Veerle Vanderheyden ${ }^{\mathrm{a}, 1}$, Takuya Wakai ${ }^{\mathrm{b}, 1}$, Geert Bultynck ${ }^{\mathrm{a}}$, Humbert De Smedt ${ }^{\mathrm{a}}$, \\ Jan B. Parys ${ }^{\mathrm{a}, * *}$, Rafael A. Fissore ${ }^{\mathrm{b}, *}$ \\ a Laboratory of Molecular and Cellular Signalling, Department of Molecular Cell Biology, K.U. Leuven, Campus Gasthuisberg, OEN1 Bus 802, B-3000 Leuven, Belgium \\ b Department of Veterinary and Animal Sciences, University of Massachusetts, Amherst, MA 01003, USA
}

\section{A R T I C L E I N F O}

\section{Article history:}

Received 27 February 2009

Received in revised form 27 April 2009

Accepted 28 April 2009

Available online 30 May 2009

\section{Keywords:}

Calcium

Mammalian eggs

$\mathrm{IP}_{3} \mathrm{R}$

Plk1

MPM-2 phosphorylation

Oocyte maturation

\begin{abstract}
A B S T R A C T
Egg activation and further embryo development require a sperm-induced intracellular $\mathrm{Ca}^{2+}$ signal at the time of fertilization. Prior to fertilization, the egg's $\mathrm{Ca}^{2+}$ machinery is therefore optimized. To this end, during oocyte maturation, the sensitivity, i.e. the $\mathrm{Ca}^{2+}$ releasing ability, of the inositol 1,4,5-trisphosphate receptor type $1\left(\mathrm{IP}_{3} \mathrm{R} 1\right)$, which is responsible for most of this $\mathrm{Ca}^{2+}$ release, markedly increases. In this study, the recently discovered specific Polo-like kinase (Plk) inhibitor BI2536 was used to investigate the role of Plk1 in this process. BI2536 inactivates Plk1 in oocytes at the early stages of maturation and significantly decreases $\mathrm{IP}_{3} \mathrm{R} 1$ phosphorylation at an MPM-2 epitope at this stage. Moreover, this decrease in Plk1-dependent MPM-2 phosphorylation significantly lowers $\mathrm{IP}_{3} \mathrm{R} 1$ sensitivity. Finally, using in vitro phosphorylation techniques we identified $\mathrm{T}^{2656}$ as a major Plk1 site on $\mathrm{IP}_{3} \mathrm{R} 1$. We therefore propose that the initial increase in $\mathrm{IP}_{3} \mathrm{R} 1$ sensitivity during oocyte maturation is underpinned by $\mathrm{IP}_{3} \mathrm{R} 1$ phosphorylation at an MPM-2 epitope(s).
\end{abstract}

(c) 2009 Elsevier Ltd. All rights reserved.

\section{Introduction}

Prior to fertilization, the mammalian egg is arrested at metaphase of meiosis II (MII), until the sperm induces a dramatic increase in the egg's intracellular $\mathrm{Ca}^{2+}$ concentration $\left(\left[\mathrm{Ca}^{2+}\right]_{\mathrm{i}}\right)$. This increase in $\left[\mathrm{Ca}^{2+}\right]_{i}$ will induce all the subsequent events of egg activation, including cortical granule exocytosis, resumption of meiosis, extrusion of the second polar body (2PB), pronucleus (PN) formation and entry into first mitosis $[1,2]$.

In mammals, the sperm-induced $\left[\mathrm{Ca}^{2+}\right]_{i}$ signal consists of $\left[\mathrm{Ca}^{2+}\right]_{i}$ oscillations that last for several hours [3]. In order to give rise to this specific spatio-temporal $\left[\mathrm{Ca}^{2+}\right]_{i}$ oscillation pattern at fertilization, the $\mathrm{Ca}^{2+}$-release machinery of the mammalian oocyte is optimized during maturation. For instance, when immature germinal vesicle (GV) oocytes are fertilized in vitro, the sperm-induced $\left[\mathrm{Ca}^{2+}\right]_{\mathrm{i}}$ oscillations are fewer in number and each $\left[\mathrm{Ca}^{2+}\right]_{\mathrm{i}}$ rise shows a smaller amplitude and duration than those observed in MII eggs $[4,5]$. The $\mathrm{Ca}^{2+}$ channel responsible for most of this $\mathrm{Ca}^{2+}$ release

\footnotetext{
* Corresponding author at: Paige Laboratories, Department Veterinary and Animal Sciences, University of Massachusetts, Amherst, MA 01003, USA.

Tel.: +1 413545 5548; fax: +1 4135456326 .

** Corresponding author. Tel.: +32 16 345736; fax: +32 16345991 .

E-mail addresses: jan.parys@med.kuleuven.be (J.B. Parys),

rfissore@vasci.umass.edu (R.A. Fissore).

${ }^{1}$ Both authors contributed equally to this work.
}

is the inositol 1,4,5-trisphosphate $\left(\mathrm{IP}_{3}\right)$ receptor type $1\left(\mathrm{IP}_{3} \mathrm{R} 1\right)$ [3], which is localized in the endoplasmic reticulum (ER). During oocyte maturation, the $\mathrm{IP}_{3} \mathrm{R} 1$ undergoes important changes, including an increase in its concentration [6,7] and a change in its cellular distribution [6-8], which may bring about the enhanced $\mathrm{IP}_{3} \mathrm{R} 1$ sensitivity, i.e. increased $\mathrm{IP}_{3} \mathrm{R} 1$-mediated $\mathrm{Ca}^{2+}$ release, that is observed at the conclusion of maturation [4]. It is thought that these changes underlie the greater ability of eggs, compared to GV oocytes, to mount persistent $\left[\mathrm{Ca}^{2+}\right]_{i}$ oscillations. Nevertheless, other cytoplasmic parameters are also optimized during oocyte maturation, although how they impact the egg's ability to mount oscillations is not well understood. For example, a significant increase in the $\left[\mathrm{Ca}^{2+}\right]_{\mathrm{ER}}[5]$ is observed during this period, and the ER itself undergoes a cellular redistribution [9-11] spreading from its area of concentration around the spindle at the MI stage to a more spread out distribution in MII eggs with conspicuous cortical clusters. Finally, changes in the activity of $\mathrm{Ca}^{2+}$ entry pathways may also be involved $[12,13]$, although their identity and function remain unexplored.

Until now, only the effect of $\mathrm{IP}_{3} \mathrm{R} 1$ concentrations has been thoroughly investigated and results show that this parameter has a role in optimizing $\mathrm{Ca}^{2+}$ release during oocyte maturation [14]. However, given the modest increase in $\mathrm{IP}_{3} \mathrm{R} 1$ mass during maturation, this parameter alone can not completely explain the increased ability of eggs to release $\mathrm{Ca}^{2+}$ at the MII stage [14]. Hence, taking into account that $\left[\mathrm{Ca}^{2+}\right]_{\mathrm{i}}$ oscillations, $\mathrm{IP}_{3} \mathrm{R} 1$ sensitivity, and ER cortical cluster for- 
mation are all maximal at the MII stage, and minimal at interphase [15], it is logical to propose that the same M-phase kinases that control the initiation and progression of meiosis [16,17] might also be regulating $\mathrm{IP}_{3} \mathrm{R} 1$ function and $\mathrm{Ca}^{2+}$ release in eggs. Towards this end, we have previously reported that $\mathrm{IP}_{3} \mathrm{R} 1$ is phosphorylated in a cell-cycle dependent manner at an MPM-2 epitope [18,19], which is commonly phosphorylated by $\mathrm{M}$-phase kinases. This modification seemed to affect $\mathrm{IP}_{3} \mathrm{R} 1$-mediated $\left[\mathrm{Ca}^{2+}\right]_{\mathrm{i}}$ oscillations [19]. Importantly, IP $\mathrm{I}_{3} \mathrm{R} 1$ becomes first phosphorylated at an MPM-2 epitope(s) at the beginning of maturation and it is almost maximal after $3 \mathrm{~h}$ $[19,20]$, which coincides with the initial increase in $\mathrm{IP}_{3} \mathrm{R} 1$ sensitivity observed during oocyte maturation $[4,5]$.

Phosphorylation of different $\mathrm{IP}_{3} \mathrm{R}$ isoforms by various kinases in somatic cells generally increases $\mathrm{IP}_{3}$-induced $\mathrm{Ca}^{2+}$ release (IICR) $[21,22]$. However, most of the kinases known to phosphorylate $\mathrm{IP}_{3} \mathrm{Rs}$ are not involved in cell cycle regulation and/or inhibition of their activity does not affect $\mathrm{IP}_{3} \mathrm{R} 1$ function in eggs [23-25]. Recently, cyclin-dependent kinase 1 (CDK1), also known as maturation promoting factor (MPF), and extracellular signal-regulated kinase (ERK1/2), also known as mitogen activated protein kinase (MAPK), two M-phase kinases known to be involved in the regulation of oocyte maturation, have been shown to phosphorylate $\mathrm{IP}_{3} \mathrm{Rs}$ [26-29]. Importantly, both kinases can phosphorylate MPM-2 epitopes on their substrates but whether they are responsible for the MPM-2 phosphorylation of $\mathrm{IP}_{3} \mathrm{R} 1$ has not yet been elucidated. Interestingly, we found that inhibition of the MAPK pathway affects both $\mathrm{IP}_{3} \mathrm{R} 1 \mathrm{MPM}-2$ phosphorylation and the $\left[\mathrm{Ca}^{2+}\right]_{\mathrm{i}}$-oscillating capability of the egg, which first suggested that MPM-2 phosphorylation of $I P_{3} R 1$ might indeed increase $\mathrm{IP}_{3} \mathrm{R} 1$ sensitivity during maturation [19]. Although MAPK is important to maintain $\mathrm{IP}_{3} \mathrm{R} 1 \mathrm{MPM}-2$ phosphorylation, its effects however become more evident towards the late stages of oocyte maturation and are possibly not associated with the initial MPM-2 phosphorylation of the receptor [20].

Another M-phase kinase that is known to phosphorylate MPM2 epitopes is Polo-like kinase 1 (Plk1) [30]. Importantly for this study, Plk1 is also involved in the G2 to M phase transition in oocytes and is required for the completion of meiosis after fertilization [31,32]. In a previous study, we showed that Plk1 appeared directly responsible for the majority of $\mathrm{IP}_{3} \mathrm{R} 1 \mathrm{MPM}-2$ phosphorylation at the beginning of oocyte maturation [20] while MAPK regulated MPM-2 phosphorylation between MI and MII [19,20]. Therefore, our goals in this study were to investigate the functional effects of Plk1-mediated MPM-2 phosphorylation of $\mathrm{IP}_{3} \mathrm{R} 1$ during oocyte maturation and to identify possible Plk1 phosphorylation site(s) on $\mathrm{IP}_{3} \mathrm{R} 1$. Using the Plk-specific inhibitor BI2536 we found that inhibition of Plk1 activity at the beginning of oocyte maturation diminished MPM-2 phosphorylation of $\mathrm{IP}_{3} \mathrm{R} 1$. Moreover, BI2536-treated oocytes showed decreased IICR compared to control oocytes. Finally, we identified $\mathrm{T}^{2656}$ as a Plk1 phosphorylation site on $\mathrm{IP}_{3} \mathrm{R} 1$.

\section{Materials and methods}

\subsection{Reagents}

All chemicals were purchased from Sigma, unless otherwise mentioned. Active His-Plk1 was purchased from Invitrogen Ltd. and radioactive ATP ([ $\left.\gamma-{ }^{32} \mathrm{P}\right]$ ATP) from PerkinElmer. All peptides were synthesized in their amidated form and purified (>95\%) by HPLC unless otherwise mentioned (Thermo Fisher Scientific GmbH). Peptides were diluted in DMSO.

\subsection{Collection of oocytes and culture conditions}

GV oocytes were collected from the ovaries of CD-1 female mice. Females were injected with 5 IU pregnant mare serum gonadotropin (PMSG) and GV oocytes were recovered $42-46$ h postPMSG into HEPES-buffered Tyrode-Lactate solution (TL-HEPES) supplemented with $5 \%$ heat-treated fetal calf serum (FCS; Gibco) and $100 \mu \mathrm{M}$ 3-isobutyl-1-methylxanthine (IBMX). GV oocytes were matured in Chatot, Ziomek, and Bavister (CZB) medium [33] containing $0.1 \%$ polyvinyl alcohol (PVA) at $36.5^{\circ} \mathrm{C}$ under an atmosphere of $6 \% \mathrm{CO}_{2}$.

\subsection{Antibodies}

Immunological detection of $\mathrm{IP}_{3} \mathrm{R} 1$ was carried out using the Rbt03 polyclonal antibody raised against C-terminal amino acids 2735-2749 of mouse $\mathrm{IP}_{3} \mathrm{R} 1$ [34]. For simultaneous detection of $\mathrm{IP}_{3} \mathrm{R} 1$ and $\mathrm{IP}_{3} \mathrm{R} 3$, the panspecific antibody $\mathrm{Rbt} 475$ was used, the epitope of which (amino acids 127-141 of mouse $\mathrm{IP}_{3} \mathrm{R} 1$ ) is conserved between isoforms and across species [35]. The anti-GST antibody (Zymed Laboratories) was used to detect the different GST-IP ${ }_{3}$ R1 domains. The MPM-2 monoclonal antibody (Upstate biotechnology) was used to ascertain $\mathrm{IP}_{3} \mathrm{R} 1$ phosphorylation as previously reported [19]. Total Plk1 was detected by the use of a rabbit polyclonal antibody against human Plk1 (Cell Signaling Technology).

\subsection{Preparation of pharmacological inhibitors}

BI2536 (Axon Medchem), a recently discovered specific Plk inhibitor [36], was dissolved in DMSO (5 mM stock) and further diluted in CZB-PVA medium or phosphorylation buffer to its final concentration.

\section{5. $I P_{3} R 1$ GST constructs and mutagenesis}

For domain analysis we expressed GST-fusion proteins corresponding to the various $\mathrm{IP}_{3} \mathrm{R} 1$ domains that can be obtained by limited proteolysis [37] as described previously [19]. $\mathrm{T}^{2656}$ was mutated into an $\mathrm{A}$ by using pGEX6p2- $\mathrm{IP}_{3} \mathrm{R} 1$ domain 6 as a template. Site-directed mutagenesis was performed using the Quick-Change point-mutation kit (Stratagene). Forward primers were designed according to the manufacturer's recommendation and reverse primers were the complementary sequence of the forward primers. This construct was sequenced to confirm mutation and frame. All GST-fusion proteins were purified as previously described [38].

\subsection{In vitro phosphorylation of $I P_{3} R 1$ and 3 by Plk1}

Full-length mouse $\mathrm{IP}_{3} \mathrm{R} 1$ and full-length rat $\mathrm{IP}_{3} \mathrm{R} 3$ were expressed in Sf9 insect cells and microsomes were prepared as described previously [39]. Sf9 microsomes $(2 \mu \mathrm{g})$ or GST-IP 3 R1 domains $(0.5 \mu \mathrm{g})$ were diluted in phosphorylation buffer $(50 \mathrm{mM}$ Hepes pH 7.5; $10 \mathrm{mM} \mathrm{MgCl}_{2} ; 2.5 \mathrm{mM}$ DTT; $0.01 \%$ Triton X-100; $200 \mu \mathrm{M}$ ATP) supplemented with $20 \mu \mathrm{Ci}\left[\gamma^{32} \mathrm{P}\right]$ ATP. Reactions were performed at $30^{\circ} \mathrm{C}$ for $1 \mathrm{~h}$ and initiated by the addition of $250 \mathrm{ng}$ (for GST-IP ${ }_{3} \mathrm{R} 1$ fragments) or $400 \mathrm{ng}$ (for Sf9-microsomes) of the active His-Plk1 kinase (Invitrogen). Reactions were stopped by heating the samples for $10 \mathrm{~min}$ at $70^{\circ} \mathrm{C}$ in $1 \times$ Laemmli sample buffer (LSB).

\subsection{Immunoblotting}

Cell lysates from 25 to 35 mouse oocytes were prepared by adding $5 \mu \mathrm{l} 2 \times$ LSB and then boiling these for $10 \mathrm{~min}$ at $70{ }^{\circ} \mathrm{C}$. Samples were loaded onto NuPAGE Novex 3-8\% Tris-acetate gel (Invitrogen). After electrophoresis, proteins were transferred onto nitrocellulose membranes and probed with MPM-2 antibody (1/500). After stripping, the membranes were probed with Rbt03 antibody (1/1000). Membranes were developed, digitally captured 
and quantified as described [19]. The intensity of the MPM-2 reactive band from GVBD oocytes was arbitrarily given the value of 1 and values in other lanes were expressed relative to this band.

After Plk1-mediated in vitro phosphorylation of $\mathrm{GST}_{-} \mathrm{IP}_{3} \mathrm{R} 1$ domains or of Sf9-microsomes expressing $\mathrm{IP}_{3} \mathrm{Rs}$, proteins were loaded onto NuPAGE Novex $4-12 \%$ Bis-tris or $3-8 \%$ Tris-acetate (Invitrogen) gels, respectively. After electrophoresis, proteins were transferred onto polyvinylidene difluoride (PVDF) membranes and incorporation of $\gamma-{ }^{32} \mathrm{P}$ was determined using the Storm 840 PhosphorImager (Molecular Dynamics) as previously described [40]. Subsequently the blot was probed with anti-GST antibody $(1 / 2000)$ or Rbt475 antibody (1/1000), respectively, to verify identical loading. After extensive washing, alkaline phosphataselabeled anti-rabbit antibody was used as secondary antibody. The immunoreactivity was visualized by conversion of the Vistra ${ }^{\mathrm{TM}}$ ECF substrate into a fluorescent probe (Amersham) and scanned with the Storm 840 FluorImager, equipped with the Imagequant NT4.2 software (Molecular Dynamics). Quantification of the phosphorylation level was performed by comparing the radioactive signal of the GST-domain or full-size $\mathrm{IP}_{3} \mathrm{R}$ to the total amount of, respectively, GST-domain or full-size $\mathrm{IP}_{3} \mathrm{R}$ as estimated by Western blotting.

\subsection{Fluorescence recordings and $\left[\mathrm{Ca}^{2+}\right]_{i}$ determinations}

To analyze the $\mathrm{Ca}^{2+}$-store content of the oocyte, oocytes were first loaded with Fura-2AM as previously described [41]. Oocytes were placed in $\mathrm{Ca}^{2+}$-free TL-Hepes with $1 \mathrm{mM}$ EGTA for $30 \mathrm{~min}$, after which they were treated with $10 \mu \mathrm{M}$ thapsigargin. Fluorescence recordings and $\left[\mathrm{Ca}^{2+}\right]_{i}$ determinations were performed as described [19].

To analyze the IICR of the oocyte, caged $\mathrm{IP}_{3}(0.25 \mathrm{mM})$ was microinjected into oocytes using the previously reported technique [19]. $\mathrm{IP}_{3}$-injected oocytes were loaded with $1 \mathrm{mM}$ Fluo-4AM (Molecular Probes) supplemented with $0.02 \%$ pluronic acid (Molecular Probes) for $20 \mathrm{~min}$ at room temperature. Fluo-4 (excitation at $480 \mathrm{~nm}$ and emission at $510 \mathrm{~nm}$ ) was chosen since its excitation wavelength $(480 \mathrm{~nm})$ does not interfere with the uncaging of $\mathrm{IP}_{3}$ $(360 \mathrm{~nm}) .\left[\mathrm{Ca}^{2+}\right]_{\mathrm{i}}$ monitoring was performed in drops of $\mathrm{Ca}^{2+}$-free TL-HEPES using a Nikon Diaphot microscope fitted for fluorescence measurements. UV light to photolyze caged $\mathrm{IP}_{3}$ was provided by a $75 \mathrm{~W}$ Xenon arc lamp and passed through a filter cube equipped with a 360/480 excitation filter. The emitted light above $510 \mathrm{~nm}$ was collected by a cooled Photometrics SenSys CCD camera (Roper Scientific). Fluo-4 fluorescence was obtained after $50 \mathrm{~ms}$ of UV exposure and the intensity was modulated using neutral density filters. $\left[\mathrm{Ca}^{2+}\right]_{i}$ values were monitored using the software SimplePCI
(C-Imaging System), which controls the frequency and duration of photolysis.

\subsection{Statistical analysis}

Values from three or more experiments performed on different batches of oocytes were analyzed by one-way ANOVA followed by Fisher's protected least significant difference test using the STATVIEW (Abacus Concepts, Inc.) program. Differences were considered significant at $p<0.05$. Values are given as means \pm S.E.M.

\section{Results}

\subsection{Plk1-mediated MPM-2 phosphorylation of $I P_{3} R 1$ increases IICR in mouse oocytes}

The effects of Plk1-mediated MPM-2 phosphorylation on $\mathrm{IP}_{3} \mathrm{R} 1$ sensitivity were until now difficult to ascertain, at least in part, due to the lack of a specific Plk1 inhibitor. Thus, the recent finding that the small molecule BI2536 specifically inhibits Plks [36] has provided a new tool to probe the role of Plk1 on IICR. To first determine whether BI2536 was capable of inhibiting Plk1 activity in oocytes, we evaluated two commonly known consequences of Plk1 inhibition. Firstly, because inhibition of Plk1 activity delays GVBD $[42,43]$, we examined the rate of GVBD in oocytes matured in medium supplemented with BI2536. Secondly, given that Plk1 plays an important role in the formation of the spindle poles, inhibition of Plk1 activity should compromise meiotic progression [44] and therefore BI2536-treated oocytes should also fail to extrude the 1 st polar body (1PB) $[42,43]$. Accordingly, GV oocytes were matured in the presence of increasing concentrations of BI2536 and the time to GVBD and presence of 1 PB were examined. Our results show that $100 \mathrm{nM}$ or higher concentrations of BI2536 delayed GVBD for about $1 \mathrm{~h}$, while lower concentrations were without effect on this parameter (Fig. 1A). Moreover, extrusion of the 1PB was abrogated by $100 \mathrm{nM}$ BI2536 (Fig. 1B), while significant inhibition was already observed using $10 \mathrm{nM}$ BI2536 (Fig. 1B). These results provide evidence that BI2536 is effectively inhibiting Plk1 activity in oocytes.

Subsequently, we tested whether inhibition of Plk1 activity by BI2536 reduced $\mathrm{IP}_{3} \mathrm{R} 1 \mathrm{MPM}-2$ phosphorylation at the GVBD stage. As expected, BI2536 decreased MPM-2 reactivity of $\mathrm{IP}_{3} \mathrm{R} 1$ in a dose-dependent manner (Fig. 2), although 1 and $10 \mu \mathrm{M}$ BI2536 produced nearly comparable suppression of MPM-2 phosphorylation $(p<0.015)$. Importantly, even at the highest BI2536 concentration, $\sim 40 \%$ of MPM-2 reactivity remained present (Fig. 2 ), suggesting that
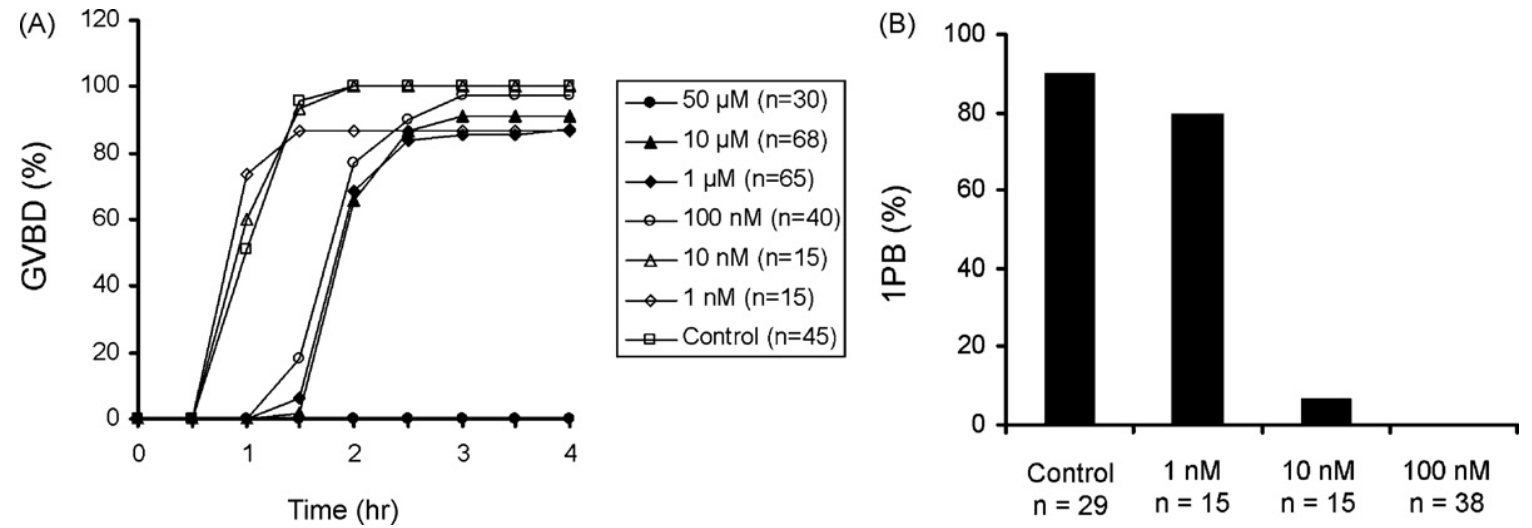

Fig. 1. Inactivation of Plk1 by BI2536 delays germinal vesicle breakdown (GVBD) and inhibits extrusion of the first polar body (1PB) in mouse oocytes. (A) Percentage (\%) of oocytes, which are matured in medium supplemented without or with the indicated concentrations of BI2536, that underwent germinal vesicle breakdown (GVBD) at different times of in vitro maturation. (B) Percentage (\%) of oocytes that extruded their first polar body (1PB) after $12-15 \mathrm{~h}$ of in vitro maturation in medium containing 0 nM (control), $1 \mathrm{nM}, 10 \mathrm{nM}$ or $100 \mathrm{nM} \mathrm{BI} 2536$. 
(A)

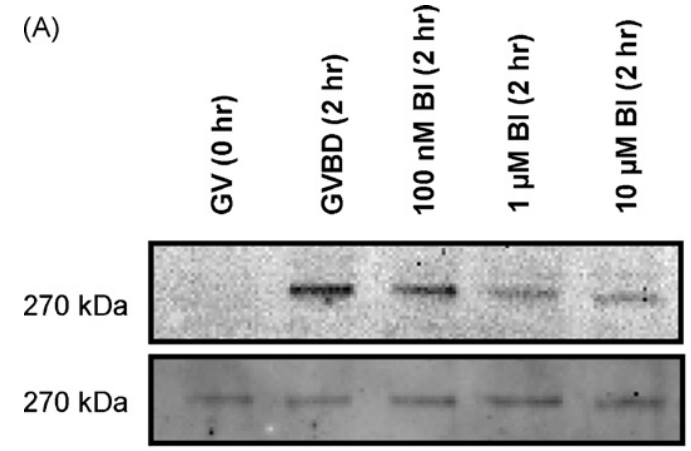

IB: MPM-2

IB: Rbt03
(B)

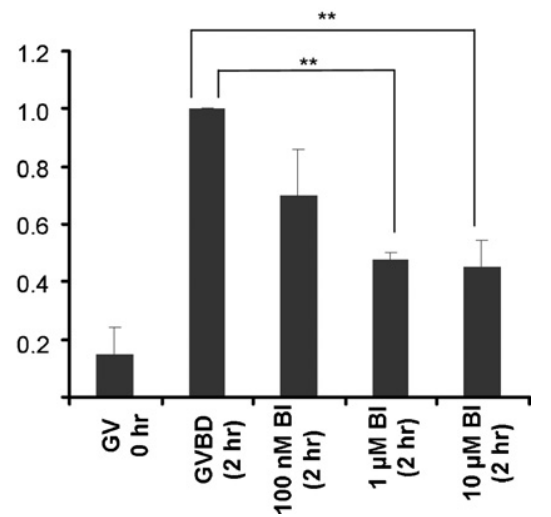

Fig. 2. Inhibition of Plk1 activity by BI2536 decreases $I_{3}$ R1 MPM-2 reactivity in GVBD oocytes. (A) Immunoblotting of oocyte lysates collected at $0 \mathrm{~h}$ (GV) or $2 \mathrm{~h}$ (GVBD) and treated with the indicated concentrations of BI2536 (BI). The blot was probed with an MPM-2 antibody and after stripping re-probed with an anti-IP ${ }_{3} \mathrm{R} 1$ (Rbt03) antibody. (B) Quantification of $\mathrm{IP}_{3}$ R1 MPM-2 reactivity. The intensity of the MPM-2 reactive band from GVBD oocytes was arbitrarily given the value of 1 and values in the other lanes were expressed relative to this band $\left({ }^{* *} p<0.015\right)$.

another kinase may also be phosphorylating $\mathrm{IP}_{3} \mathrm{R} 1$ at an MPM-2 epitope at this stage.

As the addition of BI2536 effectively suppressed Plk1 activity and decreased $\mathrm{IP}_{3} \mathrm{R} 1 \mathrm{MPM}-2$ reactivity in oocytes, we used this inhibitor to investigate how MPM-2 reactivity affected $\mathrm{IP}_{3} \mathrm{R} 1$ sensitivity. We therefore compared IICR in GVBD oocytes matured for $2 \mathrm{~h}$ in medium supplemented with and without $10 \mu \mathrm{M}$ BI2536. If Plk1 phosphorylation of $\mathrm{IP}_{3} \mathrm{R} 1$ plays a role in receptor sensitivity, we would expect $\mathrm{Ca}^{2+}$ release in BI2536-treated GVBD oocytes to be smaller than in control GVBD oocytes. For this, GV and GVBD oocytes were injected with caged $\mathrm{IP}_{3}$ and IICR was measured by recording the Fluo- 4 fluorescence signal obtained after uncaging $\mathrm{IP}_{3}$ with a UV flash (Fig. 3A-D). In agreement with our hypothesis, BI2536 greatly reduced the number of GVBD oocytes (from $78 \%$ without treatment to $30 \%$ after treatment with BI2536) capable of responding to $\mathrm{IP}_{3}$ release with a $\mathrm{Ca}^{2+}$ rise (Fig. 3D; $p<0.03$ ). In the BI2536-treated GVBD oocytes still capable of releasing $\mathrm{Ca}^{2+}$, the duration of this release was 3 times shorter in BI2536-treated GVBD oocytes than in control GVBD oocytes $(p<0.03)$ while the amplitude was not significantly altered (Fig. $3 \mathrm{~A}-\mathrm{C}$ ). For comparison the data
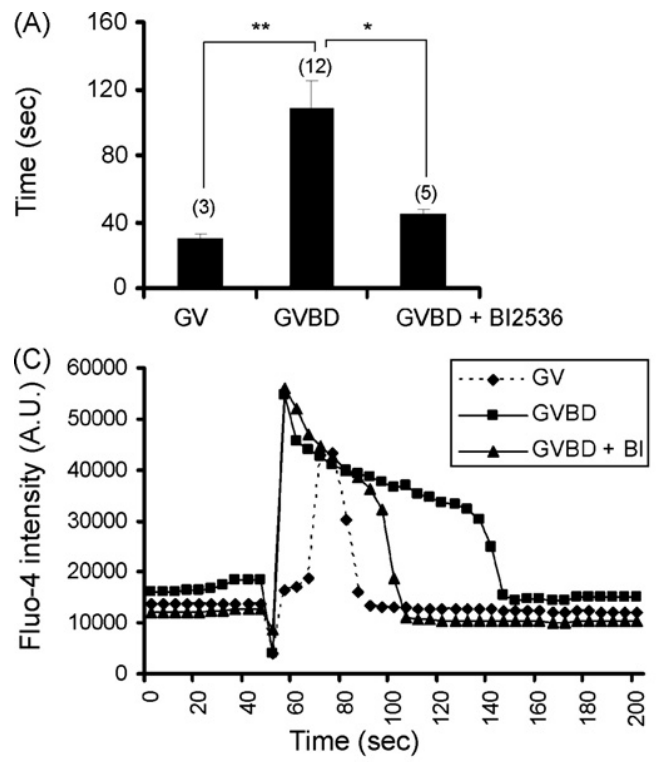

(B)

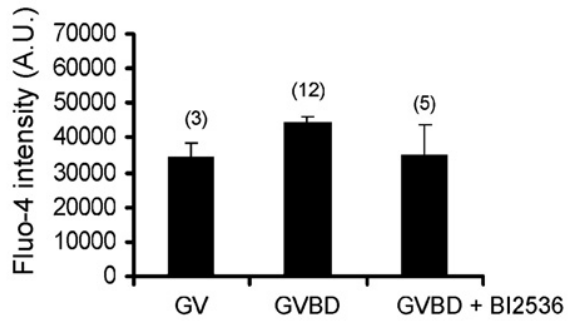

(D)

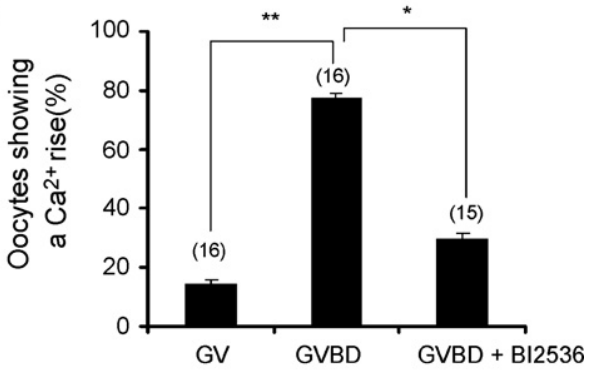

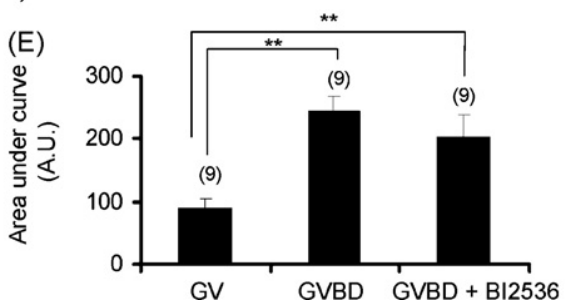

Fig. 3. BI2536 reduces the increased $\mathrm{IP}_{3}$-induced $\mathrm{Ca}^{2+}$ release (IICR) in GVBD oocytes but does not affect the Ca ${ }^{2+}$-store content. The duration $(\mathrm{A})$ and amplitude (B) of the $\mathrm{Ca}^{2+}$ rise was measured with Fluo-4 after releasing inositol 1,4,5-trisphosphate (IP $)$ by a UV-flash in GV and GVBD oocytes $+10 \mu \mathrm{M}$ BI2536. (C) A typical trace of IICR in GV, GVBD and GVBD oocytes treated with $10 \mu \mathrm{M}$ BI2536. (D) The number of GV, GVBD and GVBD oocytes treated with $10 \mu \mathrm{M}$ BI2536 that respond to IP ${ }_{3}$ with a Ca ${ }^{2+}$ rise. (E) The content of the $\mathrm{Ca}^{2+}$ stores in GV and GVBD oocytes $\pm 10 \mu \mathrm{M}$ BI2536 was estimated by measuring the area under the curve of the Ca ${ }^{2+}$ response induced by the addition of thapsigargin $(10 \mu \mathrm{M})$ in $\mathrm{Ca}^{2+}$-free media $\left({ }^{*} p<0.03 ;{ }^{* *} p<0.015\right)$. 
Table 1

Plk1 phosphorylation consensus sequences in $\mathrm{IP}_{3} \mathrm{Rs}$.

\begin{tabular}{|c|c|c|c|c|}
\hline & $\mathrm{T}^{1048}$ & $S^{1492}$ & $S^{1790}$ & $\mathrm{~T}^{2656}$ \\
\hline $\mathrm{IP}_{3} \mathrm{R} 1$ (mouse) & SEENTP-LDL & TFFSSPFSDQ & RGEMSLAEVQ & STEYTGPESY \\
\hline IP $_{3}$ R1 (human) & SEENTP-LDL & $\underline{\text { TFFSSPFSDQ }}$ & RGEMSLAEVQ & STEYTGPESY \\
\hline $\mathrm{IP}_{3} \mathrm{R} 1$ (rat) & SEENTP-LDL & TFFSSPFSDQ & RGEMSLAEVQ & STEYTGPESY \\
\hline IP $_{3}$ R1 (chicken) & RKENTP-LDL & TFFSSPFSDQ & RGEMSLADVQ & STEYTGPESY \\
\hline $\mathrm{IP}_{3} \mathrm{R1}$ (Xenopus) & SEENTP-LDL & TFFSSPFSDQ & RSEMSLSDVQ & STEYTGPESY \\
\hline IP $_{3} \mathbf{R}$ (Drosophila) & ERSDAANLDL & SFFASPFSDQ & RAGKTLHEMQ & PTEFTGPESY \\
\hline $\mathrm{IP}_{3} \mathrm{R}$ (C. elegans) & YRSSGHELHL & KFFEAPYSAL & SQERDLYAIQ & ETEFTGPESY \\
\hline $\mathrm{IP}_{3} \mathrm{R2}$ (rat) & GKTSSM-LEV & GFFNSPFSDN & PDWSAIAATQ & PTEYTGPESY \\
\hline IP $_{3} \mathbf{R 2}$ (human) & GKTSSM-LEV & $\overline{\text { GFFNSPFSD }} N$ & QDWSAIAATQ & PTEYTGPESY \\
\hline IP ${ }_{3}$ R3 (rat) & RKEKTP-VQL & $\overline{\text { AFFSSPFSEN }}$ & TG-ISMSDIQ & KTDYTGPESY \\
\hline $\mathrm{IP}_{3} \mathrm{R3}$ (human) & RKEKNP-VQL & AFFSSPFSEN & MG-ISMSDIQ & KTDYTGPESY \\
\hline
\end{tabular}

The sequences of $I_{3} R 1, I P_{3} R 2$ and $I_{3} R 3$ of various species were examined for the presence of Plk1 consensus sites. Four highly conserved Plk1 consensus sites were found in $I_{3} R 1$, centered around the phosphorylable amino acids $T^{1048}, \mathrm{~S}^{1492}, \mathrm{~S}^{1790}$ and $\mathrm{T}^{2656}$ of mouse $\mathrm{IP}_{3} \mathrm{R} 1$. Only the sequences around $\mathrm{S}^{1492}$ and $\mathrm{T}^{2656}$ were conserved in $\mathrm{IP}_{3} \mathrm{R} 2$ and $\mathrm{IP}_{3} \mathrm{R}$ 3. See text for more information. The amino acids indicated in bold are the amino acids checked for agreement and the underlined amino acids are those in agreement with the published PIK1 consensus sequences.

for GV oocytes are also shown (Fig. 3A, B, C). Given that there is a marked increase in the $\mathrm{Ca}^{2+}$ content of the ER during the transition from GV to GVBD (Fig. 3E, $p<0.015$ ), which in turn could affect the sensitivity of $\mathrm{IP}_{3} \mathrm{R} 1$, it was important to determine that BI2536 was not affecting this parameter and thereby inhibiting IICR via an indirect mechanism. Thus, we assessed whether the $\left[\mathrm{Ca}^{2+}\right]_{i}$ content of the ER, as evaluated by the $\left[\mathrm{Ca}^{2+}\right]_{\mathrm{i}}$ response induced by thapsigargin (TG), was influenced by the BI2536 treatment. Our results show that BI2536 does not significantly affect $\mathrm{Ca}^{2+}$ release by TG (Fig. 3E). Moreover, there was no difference in the duration of the TG-induced $\mathrm{Ca}^{2+}$ transient between control and BI2536-treated GVBD oocytes (data not shown) suggesting that no major changes occur in $\mathrm{Ca}^{2+}$ extrusion or $\mathrm{Ca}^{2+}$ buffering mechanisms after BI2536 treatment. We can conclude from these data that BI2536 reduces IICR through inhibition of Plk1-mediated MPM-2 phosphorylation of $\mathrm{IP}_{3} \mathrm{R} 1$. These results demonstrate that BI2536 effectively inhibits Plk1 activity in oocytes and by doing so decreases MPM-2 phosphorylation of $\mathrm{IP}_{3} \mathrm{R} 1$. Importantly, Plk1-mediated MPM-2 phosphorylation increases the sensitivity of $I_{3} R 1$ at the beginning of oocyte maturation. This is the first study demonstrating that phosphorylation of $\mathrm{IP}_{3} \mathrm{R} 1$ in oocytes plays an important role in the optimization of the egg's $\mathrm{Ca}^{2+}$-releasing capability.

\subsection{In silico prediction of possible Plk1 consensus sites in $I P_{3} R 1$}

In a previous study [20] we identified Plk1 as a major MPM-2 generating kinase of $I P_{3} R 1$ during the early stages of maturation, although the exact Plk1 phosphorylation site(s) in the receptor was not established. Therefore, we first searched in silico for possible Plk1 phosphorylation consensus sequences in $\mathrm{IP}_{3} \mathrm{R} 1$. Based on the most recently published Plk1 consensus sequence consisting of $\mathrm{X}-\phi / \mathrm{E}-\mathrm{E} / \mathrm{D}-\mathrm{E} / \mathrm{D} / \mathrm{S}-\mathrm{S} / \mathrm{T}^{*}-\phi-\mathrm{S} / \phi-\mathrm{S} / \mathrm{E} / \mathrm{D}-\mathrm{E}$ residues [45], we found only one potential site centered on $\mathrm{S}^{1492}$ of $\mathrm{IP}_{3} \mathrm{R} 1$ (Table 1 ). However, when using the earlier, simpler version of Plk1 consensus sequence that consists of $\mathrm{E} / \mathrm{D}-\mathrm{X}-\mathrm{S} / \mathrm{T}^{*}-\phi-\mathrm{X}-\mathrm{D} / \mathrm{E}$ [46], three additional sites centered on amino acids $\mathrm{T}^{1048}, \mathrm{~S}^{1790}$ and $\mathrm{T}^{2656}$ were found in $\mathrm{IP}_{3} \mathrm{R} 1$ (Table 1 ). Importantly, only the consensus sequences around $\mathrm{S}^{1492}$ and around $\mathrm{T}^{2656}$ are conserved in all $\mathrm{IP}_{3} \mathrm{R}$ isoforms and resemble possible MPM-2 consensus sites [47].

\subsection{In vitro phosphorylation of $I P_{3} R 1$ and $I P_{3} R 3$}

In vitro phosphorylation techniques were next used to identify Plk1-dependent phosphorylation sites on $\mathrm{IP}_{3} \mathrm{R} 1$. To check whether Plk1-mediated phosphorylation is conserved over the various isoforms, we subjected both $\mathrm{IP}_{3} \mathrm{R} 1$ and $\mathrm{IP}_{3} \mathrm{R} 3$ to in vitro phosphorylation. Microsomes of Sf9 insect cells overexpressing $\mathrm{IP}_{3} \mathrm{R} 1$ or $\mathrm{IP}_{3} \mathrm{R} 3$ were diluted in phosphorylation buffer containing $\left[\gamma-{ }^{32} \mathrm{P}\right]$ ATP $(20 \mu \mathrm{Ci})$ and incubated in the presence of active Plk1 for $1 \mathrm{~h}$ at $30^{\circ} \mathrm{C}$. Both $\mathrm{IP}_{3} \mathrm{R} 1$ and $\mathrm{IP}_{3} \mathrm{R} 3$ were in vitro phosphorylated by Plk1 (Fig. 4A, upper panel), and phosphorylation was quantified and normalized by comparing phosphorylation levels relative to the total amount of $\mathrm{IP}_{3} \mathrm{R}$ as detected with the polyclonal antibody Rbt475 (Fig. 4A, lower panel) that recognizes both isoforms equally well [35]. $\mathrm{IP}_{3} \mathrm{R} 3$ showed a $2.47 \pm 0.07(n=3)$ stronger phosphorylation than $\mathrm{IP}_{3} \mathrm{R} 1$, confirming that Plk1 can phosphorylate different $I_{3} R$ isoforms and suggesting that isoform-dependent differences can occur. To further confirm that the phosphorylation was indeed due to the activity of Plk1, the specific Plk inhibitor BI2536 was added to the in vitro reactions. The addition of BI2536 $(10 \mu \mathrm{M})$ decreased Plk1-mediated phosphorylation of both $\mathrm{IP}_{3} \mathrm{R}$ isoforms by $\sim 90 \%$, confirming that $\gamma^{-}{ }^{32} \mathrm{P}$ incorporation was due to Plk1 activity (Fig. 4B).

To narrow down the possible Plk1 phosphorylation sites on the full-size $\mathrm{IP}_{3} \mathrm{R} 1$, we investigated the phosphorylation properties of $\mathrm{IP}_{3} \mathrm{R} 1$ fragments. To preserve the most natural conformation that those fragments adopt in the full-size $\mathrm{IP}_{3} \mathrm{R} 1$, domains corresponding to $\mathrm{IP}_{3} \mathrm{R} 1$ fragments obtained after limited proteolysis were used

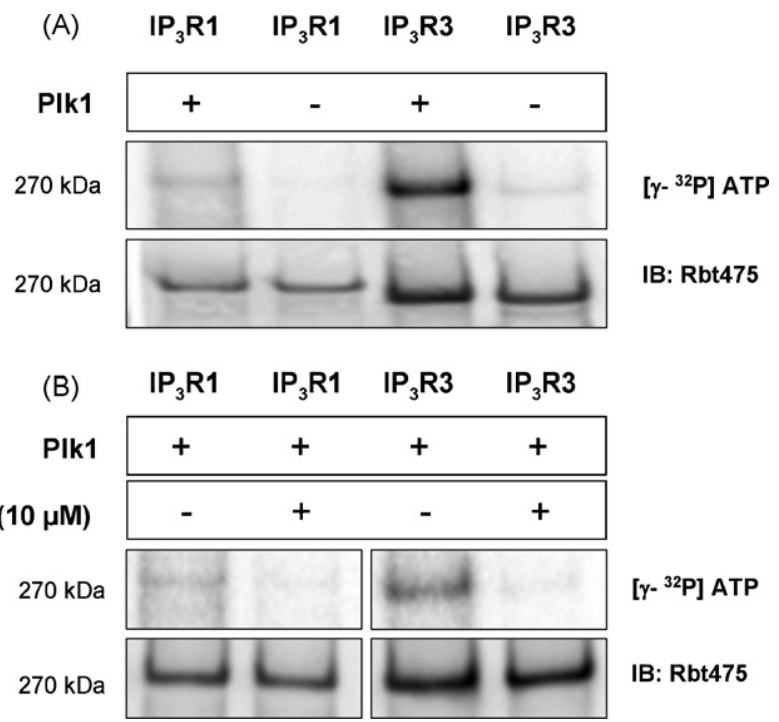

Fig. 4. Plk1 phosphorylates full-size $I P_{3} R 1$ and $I P_{3} R 3$. (A) $S f 9$ microsomes expressing full-length $\mathrm{IP}_{3} \mathrm{R} 1$ and $\mathrm{IP}_{3} \mathrm{R} 3$ were incubated with or without (negative control) Plk1 in the presence of $\left[\gamma^{32} \mathrm{P}\right]$ ATP for $1 \mathrm{~h}$ at $30^{\circ} \mathrm{C}$. (B) Plk1-mediated phosphorylation of Sf9 microsomes $\pm 10 \mu \mathrm{M}$ BI2536 (BI). Phosphorylated $\mathrm{IP}_{3}$ Rs were detected using phosphorimaging $\left(\left[\gamma_{-}{ }^{32} \mathrm{P}\right] \mathrm{ATP}\right)$ and loading of $\mathrm{IP}_{3}$ Rs was determined with an anti$\mathrm{IP}_{3} \mathrm{R}$ antibody (Rbt475) that recognizes both isoforms equally well. All results are typical of at least three experiments. 


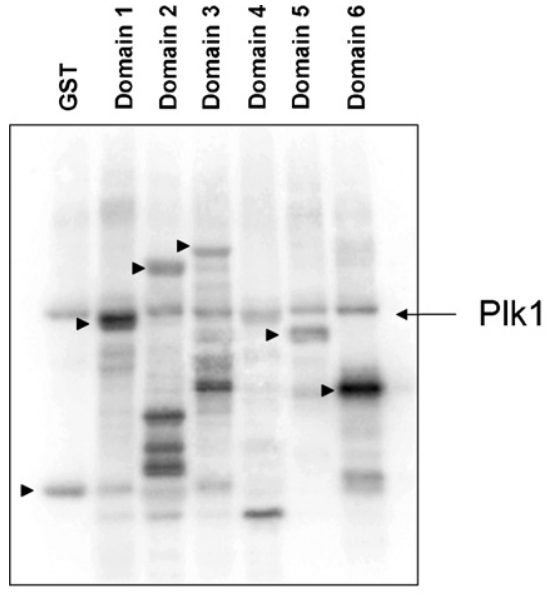

[Y- ${ }^{32}$ P]ATP

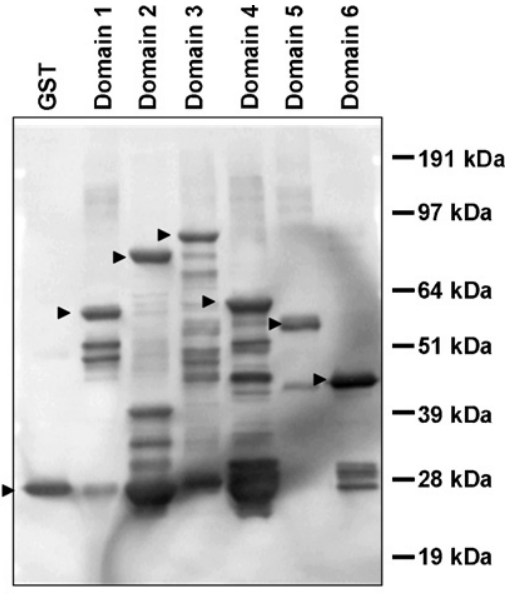

IB: GST

Fig. 5. Plk1-mediated phosphorylation of domains $1-6$ of $I P_{3} R 1$. Phosphorylation of the $\mathrm{IP}_{3} \mathrm{R} 1$ domains expressed as GST-fusion proteins was performed as in Fig. 4. Phosphorylated $I_{3}$ R1 domains were detected using phosphorimaging ( $\left.\left[\gamma^{-32} \mathrm{P}\right] A T P\right)$ (left panel) and loading of the IP ${ }_{3}$ Rs domains was determined with an anti-GST antibody (right panel). The arrow indicates the position of Plk1 (autophosphorylated) and arrowheads indicate the position of the various IP ${ }_{3} \mathrm{R} 1$-domains: domain 1 , a.a. 1-345, domain 2, a.a. 346-922, domain 3, a.a. 923-1581, domain 4, a.a. 1582-1931, domain 5, a.a. 1932-2216, domain 6, a.a. 2590-2749. Result typical of at least three experiments.

$[19,37,48]$. After the expression and purification of those domains as GST-fusion proteins, each $\mathrm{IP}_{3} \mathrm{R} 1$ domain was subjected to in vitro phosphorylation by Plk1 in the presence of $\left[\gamma^{-32} \mathrm{P}\right]$ ATP $(20 \mu \mathrm{Ci})$. The results show that domain 1 (a.a. 1-345) and domain 6 (a.a. 2590-2749) were most strongly phosphorylated by Plk1 (Fig. 5, left panel). The low level of phosphorylation observed in some of the other domains (2,3 and 5) did not differ much from the $\gamma-{ }^{32} \mathrm{P}$ incorporation observed for GST alone (negative control). Equal loading of the different GST-domains was confirmed by an anti-GST antibody (Fig. 5, right panel).

Together, those results suggest that Plk1 phosphorylation sites are most probably located in domain 1 and/or domain 6 of $\mathrm{IP}_{3} \mathrm{R} 1$, and that they may be conserved in $\mathrm{IP}_{3} \mathrm{R} 3$. Taking into account the in silico predictions, $\mathrm{T}^{2656}$ is the best candidate for phosphorylation by Plk1, as domain 6 is strongly phosphorylated and this site is conserved in $\mathrm{IP}_{3} \mathrm{R} 3$. It is noteworthy that a recognizable consensus site for Plk1 could not be found in domain 1 of $\mathrm{IP}_{3} \mathrm{R} 1$.

\subsection{Identification of $T^{2656}$ in $I P_{3} R 1$ as a Plk1 phosphorylation site}

To further investigate whether $T^{2656}$ is indeed the main site on $\mathrm{IP}_{3} \mathrm{R} 1$ phosphorylated in vitro by Plk1, we first synthesized a peptide of 20 a.a. mimicking the sequence surrounding $\mathrm{T}^{2656}$ of $\mathrm{IP}_{3} \mathrm{R} 1$ (referred to as wild type (wt) peptide; $\mathrm{NH}_{2}-$ FIVLVKVKDSTEYT ${ }^{2656}{ }^{6 P E S Y V}-\mathrm{CONH}_{2}$ ). Different concentrations of wt peptide were incubated for $1 \mathrm{~h}$ at $30^{\circ} \mathrm{C}$ with GST-domain 6 in phosphorylation buffer containing $\left[\gamma^{32}\right.$ P]ATP and active Plk1. If $\mathrm{T}^{2656}$ is the main phosphorylation site in domain 6 , the addition of increasing amounts of wt peptide into the phosphorylation reaction should compete in a dose-dependent manner with the phosphorylation site in the domain. In agreement herewith, $333 \mu \mathrm{M}$ wt peptide inhibited the phosphorylation of domain 6 by $74 \pm 3 \%$ (mean \pm S.E.M., $n=4$ ) as measured by the incorporation of $[\gamma-$ ${ }^{32}$ P]ATP (Fig. 6A). Moreover, the wt peptide itself appeared to become phosphorylated by Plk1. This result suggests that $\mathrm{T}^{2656}$ is,
(A)

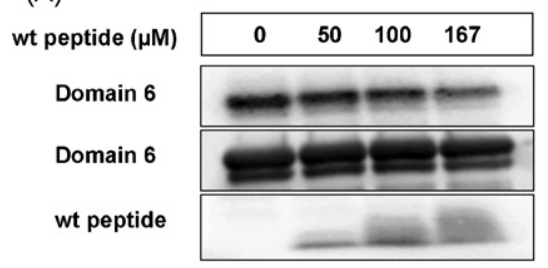

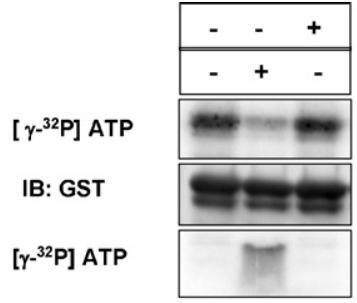

$333 \mu \mathrm{M}$ ctr peptide

$333 \mu \mathrm{M}$ wt peptide

Domain 6

Domain 6

wt peptide

(B)

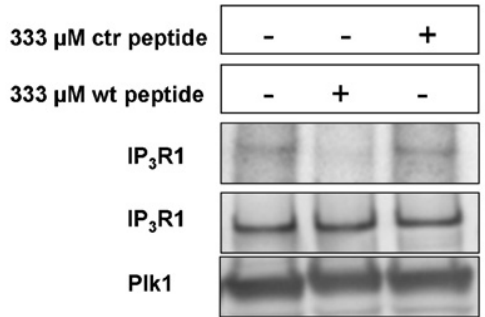

[ $\left.\gamma-{ }^{32} \mathrm{P}\right]$ ATP

IB: Rbt475

IB: PIk1

Fig. 6. wt peptide decreases Plk1-mediated phosphorylation of domain 6, and of full-size $\mathrm{IP}_{3} \mathrm{R} 1$ in vitro. Plk1-mediated in vitro phosphorylation of (A) domain $6+$ wild type (wt) peptide (left panel), domain $6+$ wt peptide or control (ctr) peptide (right panel) at the indicated concentrations. After separation by SDS-polyacrylamide electrophoresis on a $4-12 \%$ Bis-Tris gel, phosphorylated domain 6 (upper panels) and wt peptide (lower panels) were detected using a phosphorimager ([ $\left.\gamma-{ }^{32} \mathrm{P}\right]$ ATP) and loading of domain 6 (middle panels) was determined with an anti-GST antibody. (B) Plk1-mediated in vitro phosphorylation of Sf9-microsomes expressing IP ${ }_{3}$ R1 in the presence of the indicated concentrations of wt or ctr peptide. Phosphorylated $\mathrm{IP}_{3}$ Rs were detected using phosphorimaging (upper panel) and loading of $\mathrm{IP}_{3} \mathrm{Rs}$ and $\mathrm{Plk} 1$ were determined with an anti-IP ${ }_{3} \mathrm{R}$ antibody (Rbt475) and anti-Plk1 antibody, respectively. All results are typical of at least three experiments. 


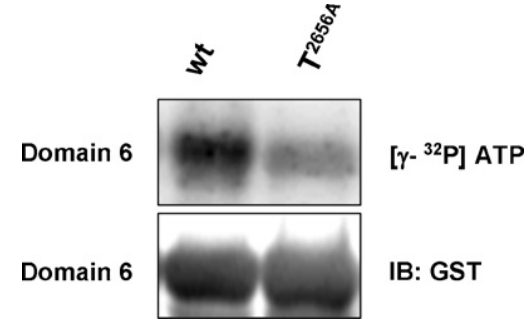

Fig. 7. Identification of $\mathrm{T}^{2656}$ as an in vitro Plk1 phosphorylation site in domain 6 of $\mathrm{IP}_{3} \mathrm{R} 1$. Plk1-mediated in vitro phosphorylation of wild type (wt) domain 6 and $\mathrm{T}^{2656 \mathrm{~A}}$ domain 6 . Phosphorylated domain 6 was detected using phosphorimaging $\left(\left[\gamma^{-32} \mathrm{P}\right]\right.$ ATP $)$ and loading of domain 6 was determined with an anti-GST antibody. The result is typical of at least three experiments.

at least in vitro, a strong target for Plk1 on domain 6. A control peptide (referred to as ctr peptide; $\mathrm{NH}_{2}$-SIVQTSFPMTFLSVDSTSFT$\mathrm{CONH}_{2}$ ) at the same concentration as the wt peptide was however completely ineffective in lowering the phosphorylation of domain 6 , demonstrating the specificity of the effect of the wt peptide (Fig. 6A, right panel). Equal loading of the different GST-domains was confirmed by an anti-GST antibody (Fig. 6A).

To extend this finding to the full-size $\mathrm{IP}_{3} \mathrm{R} 1$, the wt peptide $(333 \mu \mathrm{M})$ was incubated with Sf9 microsomes overexpressing $I_{3} R 1$, in the presence of $\left[\gamma-{ }^{32} \mathrm{P}\right] \mathrm{ATP}$ and active Plk1. The addition of wt peptide, unlike ctr peptide, here also strongly (>90\%) inhibited the incorporation of $\gamma^{-32} \mathrm{P}$ in the full-size IP 3 R1 (Fig. 6B), strongly suggesting that $\mathrm{T}^{2656}$ is an effective Plk1 phosphorylation site. Equal loading of the $\mathrm{IP}_{3}$ Rs and Plk1 was confirmed by an anti$\mathrm{IP}_{3} \mathrm{R}$ (Rbt475) and anti-Plk1 antibody, respectively (Fig. 6B).

The previous data indicate that the wt peptide is a good substrate for Plk1. However, besides $\mathrm{T}^{2656}$, the wt peptide contains two other serines and threonines that also might form targets for Plk1 phosphorylation and/or binding. Therefore, in a subsequent experiment, we mutated T $\mathrm{T}^{2656}$ in GST-domain 6 into an alanine, and investigated whether Plk1 could still phosphorylate it. After incubation under conditions that allow for Plk1-dependent phosphorylation, much less $\left[\gamma^{32}-\mathrm{P}\right]$ was incorporated in GST-domain 6 $\mathrm{T}^{2656 \mathrm{~A}}$ ( $35 \pm 4.3 \%$, mean \pm S.E.M., $n=4$ ) as compared to wild type GST-domain 6 (Fig. 7). This result implies that $\mathrm{T}^{2656}$ is indeed the major Plk1 phosphorylation site in domain 6 of $\mathrm{IP}_{3} \mathrm{R} 1$.

\section{Discussion}

Mammalian egg activation is achieved following sperm entry and the subsequent initiation of $\left[\mathrm{Ca}^{2+}\right]_{i}$ oscillations in the egg $[1,49]$. To be able to induce this signal, the $\mathrm{Ca}^{2+}$ machinery of the egg in general, and $\mathrm{IP}_{3} \mathrm{R} 1$ in particular, have to be optimized during oocyte maturation $[4,5,50]$. In somatic cells, one possible mechanism to increase $\mathrm{IP}_{3} \mathrm{R} 1$ sensitivity is through phosphorylation [21], and protein phosphorylation plays a key role in regulating oocyte maturation and meiosis resumption $[16,43,51]$. In line with this, we have shown that during oocyte maturation, $\mathrm{IP}_{3} \mathrm{R} 1$ becomes phosphorylated at an MPM-2 epitope [18-20], which is commonly the target of M-phase kinases [52]. Importantly, while we have shown that Plk1 is directly involved in this MPM-2 phosphorylation of $\mathrm{IP}_{3} \mathrm{R} 1$ [20], it was not yet known whether this modification affects $\mathrm{IP}_{3} \mathrm{R} 1$ sensitivity. Accordingly, in this study we examined whether the Plk1-mediated MPM-2 phosphorylation of $I P_{3} R 1$ underlies the increased sensitivity of $I P_{3} R 1$ observed during oocyte maturation. Our results show that the specific Plk inhibitor BI2536 suppresses Plk1 activity in oocytes and consequently decreases $\mathrm{IP}_{3} \mathrm{R} 1 \mathrm{MPM}-2$ reactivity. We also found that inhibition of MPM-2 reactivity coincided with decreased IICR in GVBD oocytes, indicating that Plk1-mediated MPM-2 phosphory- lation of $\mathrm{IP}_{3} \mathrm{R} 1$ might be one of the mechanisms increasing $\mathrm{IP}_{3} \mathrm{R} 1$ sensitivity at the beginning of oocyte maturation. Using in vitro assays, we suggest that $\mathrm{T}^{2656}$ is the preferred phosphorylation site for Plk1 in $\mathrm{IP}_{3} \mathrm{R} 1$.

\subsection{BI2536, a specific Plk inhibitor, inhibits Plk1 activity and decreases the MPM-2 reactivity of the $I P_{3} R 1$ at the early stages of oocyte maturation}

Until recently, specific Plk1 inhibitors were not available and, instead, compounds such as wortmannin and doxorubicin, which have a broad range of targets, were routinely used to block Plk1. Therefore, to confirm our previous findings that Plk1 is responsible for the MPM-2 reactivity of the $\mathrm{IP}_{3} \mathrm{R} 1$ observed during the beginning of oocyte maturation, the Plk-specific inhibitor BI2536 [36] was used. Since Plk1 is the only Plk isoform active at the G2/M transition [53], which corresponds with the beginning of oocyte maturation, this inhibitor is ideally suited to study the effects of Plk1 in oocytes. Exposure of somatic cells to BI2536 produces the same effects on mitotic progression than Plk1 RNAi: a delay into prophase and a spindle-assembly-checkpoint-induced arrest in prometaphase [44]. Other studies using mammalian oocytes showed that inhibition of Plk1 activity resulted in delayed GVBD (corresponding with delayed prophase) and absence of $1 \mathrm{~PB}$ extrusion (indicating a spindle-assembly-checkpoint arrest) $[42,43]$. Here we found that $100 \mathrm{nM}$ BI2536 was sufficient for delaying GVBD and blocking 1PB extrusion, suggesting that Plk1 was effectively inhibited during oocyte maturation.

After demonstrating the effectiveness of BI2536 in oocytes, we used this compound to inhibit the Plk1-mediated MPM-2 reactivity of $\mathrm{IP}_{3} \mathrm{R} 1$ in oocytes undergoing GVBD. BI2536 decreased MPM-2 reactivity in a dose-dependent manner and $10 \mu \mathrm{M}$ BI2536 inhibited it maximally, confirming our previous finding that Plk1 is the major MPM-2 generating kinase at the beginning of oocyte maturation [20]. Although $10 \mu \mathrm{M}$ BI2536 completely inhibited Plk1-mediated phosphorylation of $\mathrm{IP}_{3} \mathrm{Rs}$ in vitro, it did not completely inhibit MPM-2 reactivity in vivo, suggesting the presence of another MPM2 generating kinase, such as CDK1 or MAPK. We have already demonstrated that the latter kinase is not responsible for MPM-2 reactivity of $\mathrm{IP}_{3} \mathrm{R} 1$ at the beginning of oocyte maturation [20], and we therefore can safely exclude it as a candidate kinase at this stage. Importantly, in our previous study, we found that initiation of maturation by a brief pulse of okadaic acid in the presence of IBMX, which largely precludes the activation of CDK1, reduces MPM-2 reactivity of $\mathrm{IP}_{3} \mathrm{R} 1$ in MI oocytes by $30 \%$ compared to controls [20], raising the possibility that CDK1 may also function as an MPM-2 generating kinase of $\mathrm{IP}_{3} \mathrm{R} 1$ in oocytes.

\subsection{Plk1-mediated MPM-2 phosphorylation of $I P_{3} R 1$ increases the sensitivity of $I P_{3} R 1$ at the GVBD stage}

During the early stages of oocyte maturation, which encompasses the first $4 \mathrm{~h}$, there is an increase in the sensitivity of $\mathrm{IP}_{3} \mathrm{R} 1$ that is manifested by an increase in $\mathrm{Ca}^{2+}$ release [4]; this increase correlates with the appearance of Plk1-mediated MPM-2 phosphorylation of $\mathrm{IP}_{3} \mathrm{R} 1$ [20]. Our results show that $10 \mu \mathrm{M}$ of BI2536 drastically decreased the MPM-2 reactivity of $\mathrm{IP}_{3} \mathrm{R} 1$. Therefore, under the same conditions the sensitivity of $I_{3} R 1$ was examined by uncaging $\mathrm{IP}_{3}$ in the oocyte. Releasing the same amount of $\mathrm{IP}_{3}$ into BI2536-treated GVBD oocytes resulted in fewer showing a $\left[\mathrm{Ca}^{2+}\right]_{i}$ rise and those that did, exhibited $\left[\mathrm{Ca}^{2+}\right]_{\mathrm{i}}$ responses with reduced duration compared to control GVBD oocytes. In our study, the $\mathrm{Ca}^{2+}$ store content was not affected by the use of BI2536, suggesting that the decrease in MPM-2 phosphorylation was responsible for the observed decrease in $\mathrm{IP}_{3} \mathrm{R} 1$ sensitivity. 


\section{3. $T^{2656}$ is in vitro a major Plk1 site of $I P_{3} R 1$}

To elucidate the mechanism by which Plk1-mediated $\mathrm{IP}_{3} \mathrm{R} 1$ MPM-2 phosphorylation affects $\mathrm{IP}_{3} \mathrm{R} 1$ sensitivity, it is important to identify the possible Plk1 phosphorylation site(s) in the receptor. Four possible consensus sites $\left(\mathrm{T}^{1048}, \mathrm{~S}^{1492}, \mathrm{~S}^{1790}\right.$ and $\mathrm{T}^{2656}$ ) are present in full-size $\mathrm{IP}_{3} \mathrm{R} 1$ but only $\mathrm{T}^{2656}$, localized in the Cterminal part of $\mathrm{IP}_{3} \mathrm{R} 1$, was unequivocally identified in vitro as a Plk1 phosphorylation site. Mutation of $\mathrm{T}^{2656 \mathrm{~A}}$ in domain 6 significantly decreased in vitro phosphorylation of this domain while adding a wt peptide encompassing this site almost abolished the phosphorylation of full-size $\mathrm{IP}_{3} \mathrm{R} 1$. These results however do not rule out the possibility that other Plk1 sites might exist in $\mathrm{IP}_{3} \mathrm{R} 1$. In this regard, domain 1 of $\mathrm{IP}_{3} \mathrm{R} 1$ was strongly phosphorylated in vitro by Plk1, although it did not contain a recognized Plk1 consensus motif. A tempting hypothesis is that this site represents a Plk1 docking site. Plk1 docking sites consist of $\mathrm{S}-\mathrm{S} / \mathrm{T}^{*}-\mathrm{P} / \mathrm{X}$ where the $\mathrm{S} / \mathrm{T}^{*}$ has to be phosphorylated before Plk1 can bind [54]. In line with this, domain 1 has one site resembling such a docking site $\left(S-S^{278}-K\right)$. Moreover, it is known that Plk1 can phosphorylate its own docking sites [55], and our previous study suggested that in oocytes Plk1 could indeed be capable of self priming to phosphorylate $\mathrm{IP}_{3} \mathrm{R} 1$ [20]. Additional experiments will be needed to check this hypothesis.

It is not yet known how Plk1-mediated phosphorylation regulates $\mathrm{IP}_{3} \mathrm{R} 1$ sensitivity. It is possible that $\mathrm{T}^{2656}$ phosphorylation affects the gating mechanism of the receptor [56]. This hypothesis is particularly interesting because the C-terminus, also called the gate-keeper, plays an important role in determining the activity of the receptor [57,58]. Moreover, several proteins have already been identified that bind the C-terminus of the receptor and influence the conductivity of the receptor [59-61]. Alternatively, it was reported that phosphorylation by some kinases can increase $I_{3} R$ affinity for $\mathrm{IP}_{3}$ or, in some cases, determine the exact subcellular localization of $\mathrm{IP}_{3} \mathrm{R} 1$ [21]. Phosphorylation at $\mathrm{T}^{2656}$ potentially can affect $\mathrm{IP}_{3} \mathrm{R}$ sensitivity by each of these three pathways, alone or in combination.

Based on the above results, we therefore suggest that Plk1 is involved in the initial MPM-2 $\mathrm{IP}_{3} \mathrm{R} 1$ phosphorylation and as a result it increases the sensitivity of $\mathrm{IP}_{3} \mathrm{R} 1$ during early oocyte maturation. Moreover, our results suggest that Plk1 acts by phosphorylating $\mathrm{T}^{2656}$ in the C-terminal region of $\mathrm{IP}_{3} \mathrm{R} 1$. Importantly, we cannot discount that phosphorylation of other sites in the receptor, and possibly by other kinases, may contribute to MPM2 reactivity and further enhance $\mathrm{IP}_{3} \mathrm{R} 1$ sensitivity under in vivo conditions. This study is the first to reveal that phosphorylation of $\mathrm{IP}_{3} \mathrm{R} 1$ is involved in increasing the sensitivity of $\mathrm{IP}_{3} \mathrm{R} 1$ during oocyte maturation thereby contributing to prepare the oocyte for fertilization.

\section{Acknowledgements}

We thank Irène Willems and Changli He for excellent technical assistance. This work was supported by grant R01 HD051872 from the NIH to R.A.F., J.B.P and H.D.S. and by grant GOA/09/012 from the Research Council of the K.U.Leuven to J.B.P and H.D.S. V.V was recipient of a Travel Grant of the Research Foundation-Flanders (FWO).

\section{References}

[1] T. Ducibella, D. Huneau, E. Angelichio, et al., Egg-to-embryo transition is driven by differential responses to $\mathrm{Ca}^{2+}$ oscillation number, Dev. Biol. 250 (2002) 280-291.

[2] R.M. Schultz, G.S. Kopf, Molecular basis of mammalian egg activation, Curr. Top. Dev. Biol. 30 (1995) 21-62.

[3] S. Miyazaki, H. Shirakawa, K. Nakada, Y. Honda, Essential role of the inositol 1,4,5-trisphosphate receptor/ $\mathrm{Ca}^{2+}$ release channel in $\mathrm{Ca}^{2+}$ waves and
$\mathrm{Ca}^{2+}$ oscillations at fertilization of mammalian eggs, Dev. Biol. 158 (1993) 62-78.

[4] L.M. Mehlmann, D. Kline, Regulation of intracellular calcium in the mouse egg: calcium release in response to sperm or inositol trisphosphate is enhanced after meiotic maturation, Biol. Reprod. 51 (1994) 1088-1098.

[5] K.T. Jones, J. Carroll, D.G. Whittingham, Ionomycin, thapsigargin, ryanodine, and sperm induced $\mathrm{Ca}^{2+}$ release increase during meiotic maturation of mouse oocytes, J. Biol. Chem. 270 (1995) 6671-6677.

[6] L.M. Mehlmann, K. Mikoshiba, D. Kline, Redistribution and increase in cortical inositol 1,4,5-trisphosphate receptors after meiotic maturation of the mouse oocyte, Dev. Biol. 180 (1996) 489-498.

[7] R.A. Fissore, F.J. Longo, E. Anderson, J.B. Parys, T. Ducibella, Differential distribution of inositol trisphosphate receptor isoforms in mouse oocytes, Biol. Reprod. 60 (1999) 49-57.

[8] P.T. Goud, A.P. Goud, P. Van Oostveldt, M. Dhont, Presence and dynamic redistribution of type I inositol 1,4,5-trisphosphate receptors in human oocytes and embryos during in-vitro maturation, fertilization and early cleavage divisions, Mol. Hum. Reprod. 5 (1999) 441-451.

[9] G. FitzHarris, P. Marangos, J. Carroll, Changes in endoplasmic reticulum structure during mouse oocyte maturation are controlled by the cytoskeleton and cytoplasmic dynein, Dev. Biol. 305 (2007) 133-144.

[10] D. Kline, L. Mehlmann, C. Fox, M. Terasaki, The cortical endoplasmic reticulum (ER) of the mouse egg: localization of ER clusters in relation to the generation of repetitive calcium waves, Dev. Biol. 215 (1999) 431-442.

[11] L.M. Mehlmann, M. Terasaki, L.A. Jaffe, D. Kline, Reorganization of the endoplasmic reticulum during meiotic maturation of the mouse oocyte, Dev. Biol. 170 (1995) 607-615.

[12] K. Machaca, S. Haun, Induction of maturation-promoting factor during Xenopus oocyte maturation uncouples $\mathrm{Ca}^{2+}$ store depletion from store-operated $\mathrm{Ca}^{2+}$ entry, J. Cell Biol. 156 (2002) 75-85.

[13] K. Machaca, S. Haun, Store-operated calcium entry inactivates at the germinal vesicle breakdown stage of Xenopus meiosis, J. Biol. Chem. 275 (2000) 3871038715.

[14] Z. Xu, C.J. Williams, G.S. Kopf, R.M. Schultz, Maturation-associated increase in $\mathrm{IP}_{3}$ receptor type 1 : role in conferring increased $\mathrm{IP}_{3}$ sensitivity and $\mathrm{Ca}^{2+}$ oscillatory behavior in mouse eggs, Dev. Biol. 254 (2003) 163171.

[15] K.T. Jones, J. Carroll, J.A. Merriman, D.G. Whittingham, T. Kono, Repetitive sperm-induced $\mathrm{Ca}^{2+}$ transients in mouse oocytes are cell cycle dependent, Development 121 (1995) 3259-3266.

[16] M.H. Verlhac, H. de Pennart, B. Maro, M.H. Cobb, H.J. Clarke, MAP kinase becomes stably activated at metaphase and is associated with microtubule-organizing centers during meiotic maturation of mouse oocytes, Dev. Biol. 158 (1993) 330-340.

[17] E.A. Nigg, Mitotic kinases as regulators of cell division and its checkpoints, Nat. Rev. Mol. Cell Biol. 2 (2001) 21-32.

[18] T. Jellerette, M. Kurokawa, B. Lee, et al., Cell cycle-coupled $\left[\mathrm{Ca}^{2+}\right]_{i}$ oscillations in mouse zygotes and function of the inositol 1,4,5-trisphosphate receptor-1, Dev. Biol. 274 (2004) 94-109.

[19] B. Lee, E. Vermassen, S.Y. Yoon, et al., Phosphorylation of $\mathrm{IP}_{3} \mathrm{R} 1$ and the regulation of $\left[\mathrm{Ca}^{2+}\right]_{i}$ responses at fertilization: a role for the MAP kinase pathway, Development 133 (2006) 4355-4365.

[20] J. Ito, S.Y.Yoon, B. Lee, et al., Inositol 1,4,5-trisphosphate receptor 1, a widespread $\mathrm{Ca}^{2+}$ channel, is a novel substrate of polo-like kinase 1 in eggs, Dev. Biol. 320 (2008) 402-413.

[21] V. Vanderheyden, B. DeVogelaere, L. Missiaen, H. De Smedt, G. Bultynck, J.B. Parys, Regulation of inositol 1,4,5-trisphosphate-induced $\mathrm{Ca}^{2+}$ release by reversible phosphorylation and dephosphorylation, Biochim. Biophys. Acta 1793 (2009) 959-970.

[22] I. Bezprozvanny, The inositol 1,4,5-trisphosphate receptors, Cell Calcium 38 (2005) 261-272.

[23] J. Carroll, K. Swann, Spontaneous cytosolic calcium oscillations driven by inositol trisphosphate occur during in vitro maturation of mouse oocytes, J. Biol. Chem. 267 (1992) 11196-11201.

[24] J.T. Smyth, A.L. Abbott, B. Lee, et al., Inhibition of the inositol trisphosphate receptor of mouse eggs and A7r5 cells by KN-93 via a mechanism unrelated to $\mathrm{Ca}^{2+}$ /calmodulin-dependent protein kinase II antagonism, J. Biol. Chem. 277 (2002) 35061-35070.

[25] K. Swann, Y. Igusa, S. Miyazaki, Evidence for an inhibitory effect of protein kinase C on G-protein-mediated repetitive calcium transients in hamster eggs, EMBO J. 8 (1989) 3711-3718.

[26] K. Malathi, S. Kohyama, M. Ho, et al., Inositol 1,4,5-trisphosphate receptor (type 1) phosphorylation and modulation by Cdc2, J. Cell. Biochem. 90 (2003) 1186-1196.

[27] K. Malathi, X. Li, O. Krizanova, et al., Cdc2/cyclin B1 interacts with and modulates inositol 1,4,5-trisphosphate receptor (type 1) functions, J. Immunol. 175 (2005) 6205-6210.

[28] G.R. Bai, L.H. Yang, X.Y. Huang, F.Z. Sun, Inositol 1,4,5-trisphosphate receptor type 1 phosphorylation and regulation by extracellular signal-regulated kinase, Biochem. Biophys. Res. Commun. 348 (2006) 1319-1327.

[29] L.H. Yang, G.R. Bai, X.Y. Huang, F.Z. Sun, ERK binds, phosphorylates InsP $\mathrm{P}_{3}$ type 1 receptor and regulates intracellular calcium dynamics in DT40 cells, Biochem. Biophys. Res. Commun. 349 (2006) 1339-1344.

[30] E. Logarinho, C.E. Sunkel, The Drosophila POLO kinase localises to multiple compartments of the mitotic apparatus and is required for the phosphorylation of MPM2 reactive epitopes, J. Cell Sci. 111 (1998) 2897-2909. 
[31] J. Liu, J.L. Maller, Xenopus Polo-like kinase Plx1: a multifunctional mitotic kinase, Oncogene 24 (2005) 238-247.

[32] N.R. Rauh, A. Schmidt, J. Bormann, E.A. Nigg, T.U. Mayer, Calcium triggers exit from meiosis II by targeting the APC/C inhibitor XErp1 for degradation, Nature 437 (2005) 1048-1052.

[33] C.L. Chatot, C.A. Ziomek, B.D. Bavister, J.L. Lewis, I. Torres, An improved culture medium supports development of random-bred 1-cell mouse embryos in vitro J. Reprod. Fertil. 86 (1989) 679-688.

[34] J.B. Parys, H. de Smedt, L. Missiaen, M.D. Bootman, I. Sienaert, R. Casteels, Rat basophilic leukemia cells as model system for inositol 1,4,5-trisphosphate receptor IV, a receptor of the type II family: functional comparison and immunological detection, Cell Calcium 17 (1995) 239-249.

[35] G. Bultynck, K. Szlufcik, N.N. Kasri, et al., Thimerosal stimulates $\mathrm{Ca}^{2+}$ flux through inositol 1,4,5-trisphosphate receptor type 1 , but not type 3 , via modulation of an isoform-specific $\mathrm{Ca}^{2+}$-dependent intramolecular interaction, Biochem. J. 381 (2004) 87-96.

[36] M. Steegmaier, M. Hoffmann, A. Baum, et al., BI 2536, a potent and selective inhibitor of polo-like kinase 1, inhibits tumor growth in vivo, Curr. Biol. 17 (2007) 316-322.

[37] F. Yoshikawa, H. Iwasaki, T. Michikawa, T. Furuichi, K. Mikoshiba, Trypsinized cerebellar inositol 1,4,5-trisphosphate receptor. Structural and functional coupling of cleaved ligand binding and channel domains, J. Biol. Chem. 274 (1999) 316-327.

[38] G. Bultynck, P. De Smet, D. Rossi, et al., Characterization and mapping of the 12 kDa FK506-binding protein (FKBP12)-binding site on different isoforms of the ryanodine receptor and of the inositol 1,4,5-trisphosphate receptor, Biochem. J 354 (2001) 413-422.

[39] H.Sipma, P. De Smet, I. Sienaert, et al., Modulation of inositol 1,4,5-trisphosphate binding to the recombinant ligand-binding site of the type-1 inositol 1,4,5trisphosphate receptor by $\mathrm{Ca}^{2+}$ and calmodulin, J. Biol. Chem. 274 (1999) 12157-12162.

[40] E. Vermassen, R.A. Fissore, N. Nadif Kasri, et al., Regulation of the phosphorylation of the inositol 1,4,5-trisphosphate receptor by protein kinase C, Biochem. Biophys. Res. Commun. 319 (2004) 888-893.

[41] M. Kurokawa, K. Sato, H. Wu, et al., Functional, biochemical, and chromatographic characterization of the complete $\left[\mathrm{Ca}^{2+}\right]_{i}$ oscillation-inducing activity of porcine sperm, Dev. Biol. 285 (2005) 376-392.

[42] C. Tong, H.Y. Fan, L. Lian, et al., Polo-like kinase-1 is a pivotal regulator of microtubule assembly during mouse oocyte meiotic maturation, fertilization, and early embryonic mitosis, Biol. Reprod. 67 (2002) 546-554.

[43] H.Y. Fan, C. Tong, C.B. Teng, et al., Characterization of Polo-like kinase-1 in rat oocytes and early embryos implies its functional roles in the regulation of meiotic maturation, fertilization, and cleavage, Mol. Reprod. Dev. 65 (2003) 318-329.

[44] P. Lenart, M. Petronczki, M. Steegmaier, et al., The small-molecule inhibitor B 2536 reveals novel insights into mitotic roles of polo-like kinase 1, Curr. Biol. 17 (2007) 304-315.
[45] E.F. Johnson, K.D. Stewart, K.W. Woods, V.L. Giranda, Y. Luo, Pharmacological and functional comparison of the polo-like kinase family: insight into inhibitor and substrate specificity, Biochemistry 46 (2007) 9551-9563.

[46] H. Nakajima, F. Toyoshima-Morimoto, E. Taniguchi, E. Nishida, Identification of a consensus motif for Plk (Polo-like kinase) phosphorylation reveals Myt1 as a Plk1 substrate, J. Biol. Chem. 278 (2003) 25277-25280.

[47] M. Ding, Y. Feng, D.D. Vandre, Partial characterization of the MPM-2 phosphoepitope, Exp. Cell Res. 231 (1997) 3-13.

48] Y.P. Rong, A.S. Aromolaran, G. Bultynck, et al., Targeting Bcl-2-IP 3 receptor interaction to reverse Bcl-2's inhibition of apoptotic calcium signals, Mol. Cell 31 (2008) 255-265.

[49] C. Malcuit, M. Kurokawa, R.A. Fissore, Calcium oscillations and mammalian egg activation, J. Cell. Physiol. 206 (2006) 565-573.

[50] M. Terasaki, L.L. Runft, A.R. Hand, Changes in organization of the endoplasmic reticulum during Xenopus oocyte maturation and activation, Mol. Biol. Cell 12 (2001) 1103-1116.

[51] Y. Masui, From oocyte maturation to the in vitro cell cycle: the history of discoveries of Maturation-Promoting Factor (MPF) and Cytostatic Factor (CSF), Differentiation 69 (2001) 1-17.

[52] J.M. Westendorf, P.N. Rao, L. Gerace, Cloning of cDNAs for M-phase phosphoproteins recognized by the MPM2 monoclonal antibody and determination of the phosphorylated epitope, Proc. Natl. Acad. Sci. U.S.A. 91 (1994) 714-718.

[53] B.C. van de Weerdt, R.H. Medema, Polo-like kinases: a team in control of the division, Cell Cycle 5 (2006) 853-864.

[54] A.E. Elia, P. Rellos, L.F. Haire, et al., The molecular basis for phosphodependent substrate targeting and regulation of Plks by the Polo-box domain, Cell 115 (2003) 83-95.

[55] Y.H. Kang,J.E. Park, L.R. Yu, et al., Self-regulated Plk1 recruitment to kinetochores by the Plk1-PBIP1 interaction is critical for proper chromosome segregation, Mol. Cell 24 (2006) 409-422.

[56] T.S. Tang, H. Tu, Z. Wang, I. Bezprozvanny, Modulation of type 1 inositol $(1,4,5)-$ trisphosphate receptor function by protein kinase a and protein phosphatase 1alpha, J. Neurosci. 23 (2003) 403-415.

[57] K. Uchida, H. Miyauchi, T. Furuichi, T. Michikawa, K. Mikoshiba, Critical regions for activation gating of the inositol 1,4,5-trisphosphate receptor, J. Biol. Chem. 278 (2003) 16551-16560.

[58] Z.T. Schug, S.K. Joseph, The role of the S4-S5 linker and C-terminal tail in inositol 1,4,5-trisphosphate receptor function, J. Biol Chem. 281 (2006) 24431-24440.

[59] D. Boehning, S.K. Joseph, Direct association of ligand-binding and pore domains in homo- and heterotetrameric inositol 1,4,5-trisphosphate receptors, EMBO J. 19 (2000) 5450-5459.

[60] T.S. Tang, H. Tu, E.Y. Chan, et al., Huntingtin and huntingtin-associated protein 1 influence neuronal calcium signaling mediated by inositol- $(1,4,5)$ triphosphate receptor type 1, Neuron 39 (2003) 227-239.

[61] K. Kawaai, C. Hisatsune, Y. Kuroda, A. Mizutani, T. Tashiro, K. Mikoshiba, 80K-H interacts with inositol 1,4,5-trisphosphate receptors and regulates $\mathrm{IP}_{3}$-induced calcium release activity, J. Biol. Chem. (2008). 